\title{
THE POWER OF THE SMALL: THE EXAMPLE OF Paracoccidioides brasiliensis CONIDIA
}

\author{
Angela ReSTRePO(1), Luz Elena CANO(1,2) \& Ángel GONZALEZ(3)
}

\begin{abstract}
SUMMARY
Research on Paracoccidioides brasiliensis has centered in the yeast cell probably because of the lack of distinctive features in the mycelium. In 1942 and for the first time, lateral conidia were noticed in the fungus' hyphae. Later on, Brazilian, Venezuelan and Argentinean researchers described "aleurias" when the fungus was grown in natural substrates. In 1970 authors became interested in the conidia and were able to obtain them in large numbers and treat them as individual units. Their shape and size were defined and the presence of all the elements of a competent eukaryotic cell were demonstrated. Conidia exhibited thermal dimorphism and, additionally, when given intranasally to BALB/c male mice, they converted into yeasts in the lungs and produce progressive pulmonary lesions with further dissemination to other organs. Studies on the phagocyte-conidia interaction were revealing and showed that these versatile structures allow a better understanding of the host- $P$. brasiliensis interactions.
\end{abstract}

KEYWORDS: Paracoccidioides brasiliensis; Conidia, Infectious propagules; Dimorphism; Experimental paracoccidioidomycosis.

\section{INTRODUCTION}

Despite the fact that Paracoccidioides brasiliensis $(\mathrm{Pb})$, is a thermally dimorphic fungus exhibiting both a yeast (Y) - and a mycelial (M) - forms, its $\mathrm{Y}$ morphotype has been the center of most publications ${ }^{31}$ leaving aside the mycelial counterpart probably because the latter had no apparent distinctive markers ${ }^{12,30}$. The first authors that focused their attention on $P$. brasiliensis conidia were the Venezuelan scientists BORELLI ${ }^{2}$ and POLLAK ${ }^{32}$ who shortly but accurately described the propagules produced by the fungal $\mathrm{M}$ morphotype. The serendipitous observation of conidia (C) in sterilized soils seeded with a mycelium inoculum ${ }^{37}$ led to a series of research studies aimed at determining the most relevant characteristics of these propagules ${ }^{36}$. Initially the main difficulty was the fungus' scant production of these reproductive units but after some attempts, the problem was partially solved, thus opening the way to a series of experiments that demonstrated the outstanding capacities of these small (3.9-4.4 $\mu \mathrm{m})$ but resourceful fungal propagules ${ }^{3,35}$. The initial studies indicated that $\mathrm{C}$ production was a late event occurring only after prolonged (2-3 months) incubation at $20-24{ }^{\circ} \mathrm{C}$ and only when the mycelium was grown in lean media, such as water agar or dextrose salts medium $^{36}$. Slide culture observations of undisturbed mycelial growth were used to determine the $\mathrm{C}$ microscopic aspects finding that most structures represented intercalary arthroconidia but that other structures such as $\mathrm{C}$ stemming directly from the mycelium, and single-celled, pedunculated $\mathrm{C}$ could also be seen (Fig. 1) ${ }^{3}$. Due to the fact that arthroconidia constitute an integral part of the parent mycelium their detachment proved difficult and it was necessary to design a method to recover the single units needed for further experiments. Saline wetting of plates where fungal colonies had grown allowed to prepare a suspension that was shaken with glass beads, centrifuged and filtered through a glass wool column that had been left standing in the upright position for some time. Conidia present in the supernatant fluid were then counted and their viability assessed with ethidium bromide. Yield was approximately 1,000,000 C per plate ${ }^{33}$.

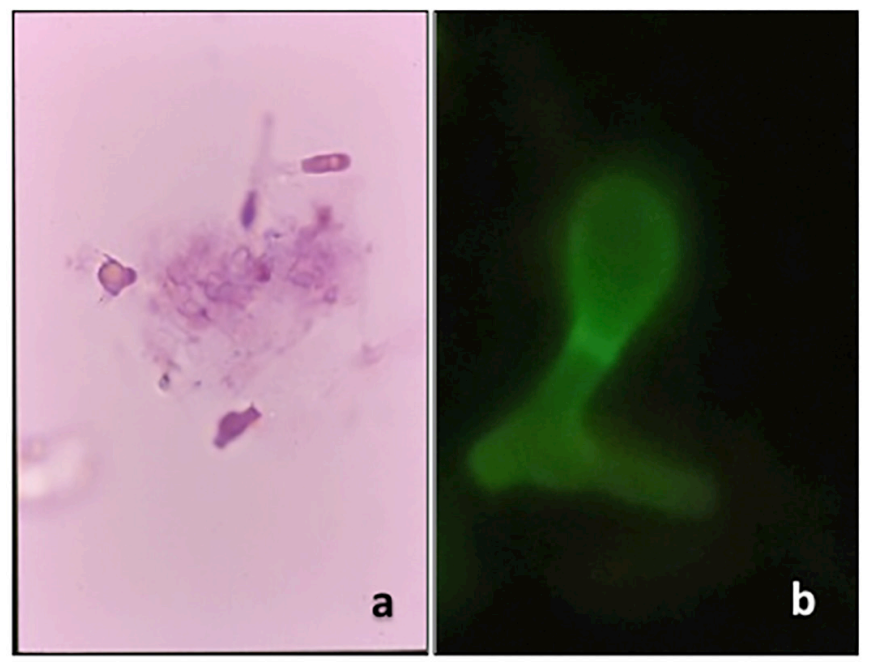

Fig. 1 - Paracoccidioides brasiliensis conidia types. A) Fresh $\mathrm{KOH}$ preparations with various conidia; b) Pedunculated conidium using a fluorescent staining.

(1) Corporación para Investigaciones Biológicas (CIB). Medical and Experimental Mycology Unit.

(2) Universidad de Antioquia. School of Microbiology.

(3) Universidad de Antioquia, Basic and Applied Microbiology Research Group (MICROBA). Medellin, Colombia.

Correspondence to: Angela Restrepo-M., Carrera 32 Nº 9 Sur-237, Phone (57-4) 313 1008, Medellín, Colombia. E-mail: angelares@une.net.co 
The $\mathrm{C}$ capacity to respond to temperature changes was then examined; slide cultures were prepared for microscopic examination and incubated at $22^{\circ} \mathrm{C}$ or at $36^{\circ} \mathrm{C}$ depending on the shift desidered, namely, conidium to mycellium or conidium to yeast. In the first case, $\mathrm{C}$ began to produce germ tubes in $24 \mathrm{~h}$ that after $96 \mathrm{~h}$ continued to give rise to mycelial elements. When at body temperature, $\mathrm{C}$ rounded up and in $72-96 \mathrm{~h}$ transitioned to Y cells, some of them exhibiting the characteristic $P$. brasiliensis multiple budding. Going from $4 \mu \mathrm{m}$ to $40 \mu \mathrm{m}$ in such short time was, indeed, a wonder. This finding was accompanied by observations showing that $80 \%$ of the uninucleated $\mathrm{C}$ incubated at $37^{\circ} \mathrm{C}$ became multinucleated when reaching the $\mathrm{Y}$ configuration ${ }^{35}$. Staining with special nuclear stains (nitromycin/acridin orange) revealed that these conidia possessed all the attributes of viable and physiologically competent eukaryotic cells ${ }^{26}$. In mature $\mathrm{C}$, the cytoplasm was densely packed with food reserves including lipid bodies, indicating that these propagules were well provided for their survival under environmental conditions ${ }^{11,39}$.

The time had come to determine the infectiousness of $P$. brasiliensis mycelial propagules for BALB/c mice. Animal inoculation was attempted with a modest number of $\mathrm{C}\left(1 \mathrm{X} 10^{6}\right)$ administered intranasally. Nonetheless, it was observed that $\mathrm{C}$ had reached the alveoli and within 12 hours had began their transition into Y cells. Eight hours later multiple-budding $\mathrm{Y}$ cells had already appeared in lung tissues. The rate of pulmonary infection was high (98\%). and was followed by an intense inflammatory reaction leading to granuloma formation and to increased numbers of actively multiplying yeast cells. In a few days dissemination had taken place and spread to the lung, liver and spleen. Thus $\mathrm{C}$ were shown to be capable of producing active disease in healthy animals. Under identical experimental circumstances, a much larger Y cells inoculum $\left(20 \times 10^{6}\right)$ was required to establish infection in BALB/c mice. Little wonders! ${ }^{25}$.

The above experiments were quite revealing and indicated that other studies could be undertaken with the conidia, most probably, the natural infectious propagules. Several lines of research were delineated during this period, as described below:

\section{In vitro interactions among host molecules and $P$. brasiliensis conidia}

One of the most important constituents of the tissues are the extracellular matrix (ECM) proteins that include fibrinogen, laminin, collagen and fibronectin, among others. It has been described that these molecules could serve as adherence substrates for several pathogens. In the case of $P$. brasiliensis conidia, it was observed that these propagules showed the ability to adhere in a dose-dependent manner to laminin, fibronectin and fibrinogen, and that this recognition is mediated by a molecule of $32-\mathrm{kDa}$ present on its surface which acts as a common receptor ${ }^{17}$. Later, sequencing analysis allowed to identify the $32-\mathrm{kDa}$ molecule as a hydrolase (PbHAD32) conserved among the fungal dimorphic and filamentous pathogens; in addition, using antisense RNA technology, this molecule was confirmed as a virulence factor ${ }^{20}$.

Besides making tissue structural part, fibrinogen is considered the major component of the coagulation system. On these lines, it was shown that $P$. brasiliensis conidia are capable to aggregate in the presence of fibrinogen and human plasma (containing fibrinogen), and the addition of anticoagulants and metabolic and protein inhibitors diminished the aggregation process; moreover, the intrinsic coagulation pathway was markedly altered when conidia were in contact previously with plasma $^{40}$. These results suggest that $P$. brasiliensis conidia interact with the coagulation system, process that could be important not only during their initial recognition, but also during the inflammatory response development and subsequent establishment of the disease.

On the other hand, interaction of $P$. brasiliensis conidia with the 17-beta-estradiol markedly reduce its transformation process to yeast morphotype, fact that support the hypothesis that female hormones is a protector factor for the development of paracoccidioidomycosis ${ }^{38}$. Later on, this hypothesis was confirmed using an in vivo model, thus male and female mice were infected with $P$. brasiliensis conidia, in the former transition of conidia-to-yeast cells in bronchoalveolar lavage fluids occurred and infection progressed whereas in female mice this process did not take place and the infection was cleared ${ }^{1}$; moreover, castrated male mice reconstituted with 17-beta-estradiol restricted the proliferation of the fungus during the initial periods of infection whereas castrated female mice reconstituted with testosterone were unable to restrict the disease ${ }^{1}$. Studies to identify the specific receptors that recognized this hormone should be addressed.

Once the $P$. brasiliensis conidia had entered to the host, they interact with their cells or other components including the ECM proteins or soluble factors. Conidia enter via inhalation and during this process these propagules initiate a travel through the nose, larynx, pharynx, trachea, reaching to the lungs and interacting with the epithelium of these components. Nonetheless, the interaction of $P$. brasiliensis conidia with cells that form part of the upper respiratory tract has not been described so far.

\section{Interactions among epithelial cells and $\boldsymbol{P}$. brasiliensis conidia}

As described above, P. brasiliensis conidia interact with ECM proteins. Of note, this fungal morphotype shows the ability to adhere and internalize into the A549 cells, a human alveolar epithelial cell line (corresponding to type II pulmonary epithelial cells) $)^{9,15}$. Moreover, it was demonstrated that laminin, fibronectin and fibrinogen were present on the surface of the A549 cells, indicating these ECM proteins could act as a bridge between $P$. brasiliensis conidia and pulmonary epithelial cells ${ }^{9,15}$. In an additional study, it was reported that the hydrolase PbHAD32, a molecule present on the conidial surface that recognizes the ECM proteins, is involved in the adherence to pulmonary epithelial cells ${ }^{20}$. These reports indicate that the recognition of ECM by $P$. brasiliensis conidia is a key process during the interaction with epithelial pulmonary cells, and could be considered as the first step in the establishment of infection.

\section{Interactions among macrophages/neutrophils and $P$. brasiliensis conidia}

Besides the interaction with pulmonary epithelial cells, P. brasiliensis conidia can interact with alveolar macrophages. It has been described that resident murine pulmonary macrophages uptake the conidia and allow these propagules to undergo the transition process to yeast morphotype if these cells are not activated; -on the contrary, when activated with supernatants from antigen-stimulated immune mononuclear cells (containing cytokines), these phagocytic cells showed the ability to kill efficiently these propagules, thus indicating that activated macrophages 
exert an important role in the pulmonary defense against this fungal infection ${ }^{5}$.

Other studies using resident peritoneal macrophages or cell lines have also been addressed. Thus, peritoneal macrophages exert an antifungal effect when activated with cytokines from antigen-stimulated spleen cells ${ }^{6}$. Later on, the use of commercially purified-cytokines such as interferon gamma (IFN- $\gamma$ ), allowed to observe that this molecule was one of the cytokines capable of activating peritoneal macrophages in a specific manner inducing the production of nitric oxide (NO), a key molecule involved in the fungicidal mechanisms exhibited by these phagocytic cells ${ }^{16}$. NO is generated by the oxidation of one of the nitrogens in the amino acid L-arginine, which serves as substrate of the inducible nitric oxide synthase (iNOS). One of the NO microbicidal mechanisms is mediated through the reaction with cellular iron or ironsulfur centers resulting in the inactivation of several essential enzymes for the microorganism invasion.

Thus, the fungicidal activity dependent on the NO production was confirmed using anti-IFN- $\gamma$ monoclonal antibodies as well as different nitric oxide inhibitors including arginase, $\mathrm{N}(\mathrm{G})$-monomethyl-L-arginine, and aminoguanidine, with all of them reverting the fungicidal effect and the NO production ${ }^{16}$. Moreover, the addition of deferoxamine (an iron chelator) to non-activated macrophages and infected with $P$. brasiliensis conidia inhibited the conidia-to yeast transition process, while supplementing infected- and IFN- $\gamma$-activated-macrophages with iron donors such as holotransferrin and $\mathrm{FeSO} 4$ reverted the fungicidal effect exerted by these phagocytic cells without affecting the NO production $^{18}$. These results clearly indicated that the fungicidal effect against $P$. brasiliensis conidia by IFN- $\gamma$-activated-macrophages through the NO production depends on the interaction with the iron. Additionally, employing the tumor necrosis factor-alpha (TNF- $\alpha$ ) to activate peritoneal macrophages, it was observed that these activated-phagocytic cells inhibited the conidia-to-yeast transition; nonetheless, this antifungal effect was independent of NO production ${ }^{14}$.

Taking into account that the mechanism by which TNF- $\alpha$ contributes to fungus control is not fully understood, other study was addressed in order to determine which mechanism could be involved; thus, it is known that lysozyme, the most abundant antimicrobial peptide present in the phagocytic cells' granules of neutrophils, macrophages, monocytes and epithelial cells is increased by the TNF- $\alpha$ stimulation and exhibit an important microbicidal effect. On these lines, TNF- $\alpha$ activated-MH-S murine alveolar macrophages cell line inhibited the $P$. brasiliensis conidia-to-yeast transition and exerted and important antifungal effect which was reverted by the addition of N, N', N" triacetylglucosamine (NAG3, a selective inhibitor of lysozyme); moreover, the transition process was also impaired by the presence of the enzyme, and in addition, exposition of the conidia to lysozyme induced ultra-structural changes such as subcellular degradation, fusion of lipid vacuoles, lamellar structures and interruption of the fibrillar layer ${ }^{22}$. These results suggested that lysozyme is involved in the antifungal mechanism against $P$. brasiliensis conidia, mechanism that is also mediated by TNF- $\alpha$.

In other study, using congenic murine bone-marrow-derived macrophage lines B10R (Nramp1rGly ${ }^{169}$ ) and B10S (null Nramp1 protein expression, Nramp1sAsp ${ }^{169}$ ) and infected with $P$. brasiliensis conidia, it was observed that those opsonized propagules where more efficiently phagocytosed by both cell lines; and the use of anti-complement receptor 3 (CR3) antibodies and alpha-methyl-D-mannoside reduced the phagocytosis process mainly in the B10R macrophages; results that indicate that the uptake of $P$. brasiliensis conidia is partially mediated by the CR3. In addition, the activation with IFN- $\gamma$ decreases the transition process $^{21}$. All the above results clearly indicate that macrophages are pivotal cells involved in the defense against $P$. brasiliensis.

Another important cell considered as the first line of defense in the host response against microbial pathogens is the neutrophil. Thus, neutrophils appear to be involved in resistance to $P$. brasiliensis infection through phagocytosis and subsequently activation of microbicidal mechanisms such as the respiratory burst; nonetheless, these mechanisms do not seen to be sufficient to kill the fungus. In addition to these defense strategies, neutrophils are able to produce extracellular traps (NETs), a structure composed mainly by decondensed chromatin with cytoplasmic proteins. NETs can be produced by NADPH oxidase activation-dependent or independent mechanism and subsequent reactive oxygen species (ROS) production, and it has been described that these structures are able to capture microbes, degrade their virulence factors and eliminate the pathogens. More recently, it has been reported that $P$. brasiliensis conidia are able to induce NET formation by human neutrophils through a mechanism independent of ROS production; however, this mechanism was ineffective in killing the fungus ${ }^{27}$.

\section{In vivo interactions with Paracoccidioides brasiliensis conidia}

Mouse animal models (MAM) are powerful tools most commonly used to elucidate the pathogenesis of human mycoses ${ }^{8}$. The current incapacity to define $P$. brasiliensis natural habitat prevents determination of the precise moment when the human host becomes infected with this fungus and consequently MAM represent an alternative to study the kinetics of the mechanisms involved in the pathogenesis of PCM.

In order to choose an appropriate MAM, several different but important factors should be considered such as age, gender and genetic traits of the experimental animal, inoculation route, morphotype and concentration of infectious inoculum. Thus, in order to study the in vivo $\mathrm{Pb}-\mathrm{C}$ host interactions, development of an experimental murine PCM pulmonary mode ${ }^{25}$ should take into consideration the following steps:

- Intranasal inoculation: a route considered to be the natural route of infection (inhalatory) ${ }^{34}$,

- $\quad$ The use of viable $P b$-C: considered to be $P$. brasiliensis natural infecting propagules ${ }^{19}$,

- Inoculation of male adult BALB/c mice: animals known to have intermediate susceptibility to $P$. brasiliensis ${ }^{4}$.

The establishment of this MAM has permitted the analyses of the immune responses taking place during the early and late stages postchallenge of the P. brasiliensis experimental infection ${ }^{7,19}$.

\section{A model of pathogenesis}

The infection is acquired by inhalation of $\mathrm{Pb}-\mathrm{C}$ that reach the pulmonary alveoli where they attach to the epithelium (Fig. 2). At 2-hours post-infection (p.i.) it is observed a mild septal infiltration with neutrophils and macrophages accompanied by an intense "cytokine burst" (IL-1 $\alpha$, IL-1 $\beta$, IL-4, IL-5, IL-6, IL-10, IL-12p70, IL-13, IL-17, Eotaxin, 
G-CSF, MCP1, MIP1 $\alpha$, GM-CSF, IFN- $\gamma$, MIP-1 $\beta$ and TNF- $\alpha)^{23}$. Ten hours later the $\mathrm{C}$ began transforming into yeast cells with multiple buds appearing by $18 \mathrm{~h}^{25}$. Later on $\mathrm{Pb}$-infected mice had a significant increase in leukocytes in the lungs during the first four days with a peak at day 2 p.i.; infiltrates were composed mainly of neutrophils, accompanied by elevated production of TNF- $\alpha$, IL-6, IL- $1 \beta$ and MIP-2, an up-regulation of ICAM-1, VCAM-1, CD18 and Mac-1 expression. Concomitantly increased expression of different ECM proteins (fibronectin, laminin and fibrinogen) was noticed, suggesting their participation in the migration of inflammatory cells into the lungs during $\mathrm{Pb}-\mathrm{C}$ infection $^{7,19}$. This inflammatory event concurred with a bronchopneumonic process in which neutrophils and macrophages accumulated and fused with each other to constitute extensive, ill-defined masses, located inside the alveolar and the surrounding peribronchiolar spaces, resulting in involvement of approximately $40 \%$ of the lung's area ${ }^{7,19}$.

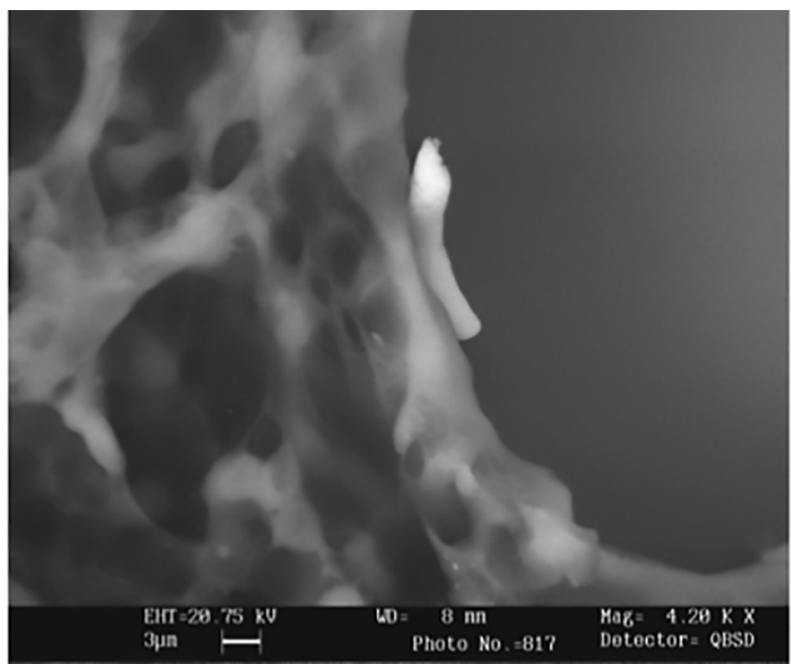

Fig. 2 - A scanning electron photomicrography from a pulmonary tissue of a BALB/c male mouse, 30 minutes after intranasal inoculation with Paracoccidioides brasiliensis conidia.

During the evolution of infection (weeks 2-12), development of granulomas was noticed; they displayed a pattern of ECM proteins including collagen type I, and in a lesser amount of collagen type III and proteoglycans. Granulomas were structurally arranged in two zones: a central zone containing fungi, and a peripheral zone formed by epithelioid and mononuclear cells while the elastic fibrous system entered into an elastolysis process ${ }^{7,19}$.

Pulmonary lesions were followed through a comparative analysis between High Resolution Computed Tomography (HRCT) and histopathologic parameters. The results showed three different patterns of lesions: nodular-diffuse, confluent and pseudo-tumoral. The lesions were mainly located around the hilus and affected more frequently the left lung. At the $4^{\text {th }}$ week p.i. HRCT showed that $80 \%$ of the $\mathrm{Pb}$-C infected mice had peri-bronchial consolidations associated with a significant increase in upper lung density when compared to controls ${ }^{7,24}$.

After the $8^{\text {th }}$ and $12^{\text {th }}$ weeks p.i. consolidation had progressed involving also the middle regions. Histopathology revealed that consolidation - as assessed by HRCT - was equivalent histologically to a confluent granulomatous reaction, while nodules corresponded to individual compact granulomas ${ }^{24}$. In addition, fungal proliferation, inflammation and collagenesis reached their highest intensity with particular involvement of the periarterial space; paradoxically, lung cytokines and chemokines were down-regulated with significant decreases in IL-2, IL-3, IL-5, IL-9, IL-13, IL-15, GM-CSF, IFN- $\gamma$, MIP1 $\beta$ and TNF- $\alpha^{23}$. At the $16^{\text {th }}$ week p.i., confluent granulomas formed pseudotumoral masses that obstructed large bronchi. Discrete focal fibrosis was visible gradually around granulomas but this finding was only evident by histopathology ${ }^{24}$. This process was accompanied by a "silent" cytokine response, except for PDGF, MIG, RANTES and IL-12p40 which remained up-regulated ${ }^{23}$.

As it concerns the role of the nitric oxide (NO) system during the chronic immune response, it was observed that iNOS (NOS2) was expressed mainly in vivo by the epithelioid histiocytes with its maximal expression occurring $12^{\text {th }}$ weeks p.i. ${ }^{7,19}$. The expression of iNOS correlated significantly $(r=0.77891)$ with the number of granulomas present in the pulmonary parenchyma ${ }^{19}$ suggesting that, at this stage, iNOS induction could depend on factors or mechanisms related to the environment inside the granuloma. In addition, the in vivo administration of aminoguanidine (a highly specific inhibitor of iNOS) to infected and non-infected mice induced in the former a significant reduction of their survival in comparison with negative control mice. These results suggest that during the chronic stages (12-16w p.i.), the NO system played an important protective role against fungal infection ${ }^{7,19}$.

In conclusion, the intranasal inoculation of $\mathrm{C}$ into $\mathrm{BALB} / \mathrm{c}$ male mice resulted in a progressive disease characterized by the following aspects: an increase in pulmonary CFUs, with maximal values at the $12^{\text {th }}$ and $16^{\text {th }}$ weeks p.i., extra-pulmonary dissemination to the spleen (week 4) and liver (week 12), an inflammatory response, cytokine production, metalloproteinase expression, NO participation, granuloma formation and, finally, the chronic pulmonary sequelae characterized by fibrosis entering into the play, as described below ${ }^{7,10,19,23-25,28,29}$.

\section{Fibrosis and therapeutic modulation}

Pulmonary fibrosis (PF) is considered the most feared sequelae of PCM in human patients who tend to exhibit important respiratory limitations ${ }^{34}$. In the MAM described above, it was determined that at four weeks p.i., when the granuloma are well shaped, thin fibers of collagen and reticulin became evident, suggesting the beginning of a fibrotic process, one that progressed simultaneously with the presence of leukocyte infiltrates surrounding the granuloma ${ }^{7,23}$.

After the $8^{\text {th }}$ week p.i., thick fibers of collagen and reticulin became evident as an indicator of established fibrosis; fibers of both proteins gradually increasing up to 12 weeks p.i. indicating that the collagenesis process had reached its highest intensity, with particular involvement of the periarterial space and the surrounding area of the granuloma, whether or not confluent.

Observations made at the $16^{\text {th }}$ week p.i. revealed a well-established pulmonary fibrosis process $s^{7,10,13,19,23-25,28,29}$. The fibrotic process was determined by the excess production and/or disarrangement of collagens I and III, and it was associated with formation of granulomas, increase in lung hydroxyproline, and sustained increases of TNF- $\alpha$ and TGF- $\beta$ in the lung tissue ${ }^{10,13}$. On the other hand, this tissue response appeared to depend on the type of inoculum employed, whether intact or fragmented 
yeast cells with the later inducing only a transitory inflammatory foci and absence of granuloma formation ${ }^{10}$.

Furthermore some aspects related to therapeutic modulation were also studied using this MAM, as follows:

- Histopathologic and immunologic effects of the itraconazole (ITC) treatment. Two different groups of mice were exposed to ITC therapy beginning at the $4^{\text {th }}$ or $8^{\text {th }}$ weeks p.i., respectively. As expected, this therapy significantly reduced the fungal burden present in infected mice and led to the following changes: i) a significant decrease in the pulmonary inflammatory response; ii) a change in the cellular infiltrate composition, with reduction of the proportion of neutrophil cells; and iii) a strong reduction of the levels of pro-inflammatory cytokines (IL-1 $\beta$ and TNF- $\alpha$ ). In contrast, changes related to the fibrotic process depended on the time of therapy initiation as a reduction in pro-fibrotic cytokine levels (IL-13 and TGF- $\beta$ ), followed by an evident decrease in the fibrotic sequelae, were observed only when the therapy was started promptly ${ }^{28}$.

- Combined ITC + pentoxifylline (PTX) treatment. This combined therapy (ITC+PTX) promptly reduced the granulomatous inflammation and caused a significant and rapid decrease of both thin reticulin and collagen fibers production. The most important result was that thick fiber deposition of these proteins, which are considered fibrosis indicators, was reduced to normal levels, as seen in the control uninfected mice, and remained low even after the end of the treatment. Considering fungal loads, it was demonstrated that the addition of PTX to ITC treatment did not produce additional deleterious effects on ITC antifungal activity; on the contrary, a tendency towards a faster reduction of fungal burdens was observed when the combined therapy was used. These beneficial effects were noted even when such combined therapy was started belatedly at eight weeks p.i., a time at which the fibrosis process was already established in the murine model ${ }^{29}$.

The fact that in mice the combined ITC+PTX therapy promptly reduced the development of pulmonary fibrosis to levels lower than those seen with antifungal therapy alone, and that this effect was maintained even after the end of treatment, presents a promising advance in the development and establishment of adjunctive immunotherapies for the treatment not only of pulmonary chronic PCM but also of several disorders or chronic infections that lead to the development of fibrosis. These findings could imply not only a reduction of treatment costs but, more importantly, improvement in the quality of life of patients with chronic pulmonary $\mathrm{PCM}^{7}$.

\section{RESUMO}

\section{O poder do pequeno: o exemplo dos conídios do Paracoccidioides brasiliensis}

A investigação sobre Paracoccidioides brasiliensis tem-se centrado na célula de levedura, provavelmente devido à falta de características distintas no micélio. Em 1942 e, pela primeira vez, conídios laterais foram notados nos hifas dos fungos. Mais tarde, pesquisadores brasileiros, venezuelanos e argentinos descreveram "aleurias" quando o fungo foi cultivado em substratos naturais. Em 1970, os autores se interessaram pelos conídios e foram capazes de obtê-los em grande número e tratá-los como unidades individuais. A sua forma e tamanho foram definidos, e a presença de todos os elementos de uma célula eucariótica competente foram demonstrados. Conídios apresentam dimorfismo térmico e, além disso, quando administrados por via intranasal a camundongos BALB/c machos, são convertidos em leveduras nos pulmões e produzem lesões pulmonares progressivas com posterior disseminação para outros órgãos. Estudos sobre a interação de fagócitos-conídios foram reveladores e mostraram que estas estruturas versáteis permitem melhor compreensão das interacções entre hospedeiro e $P$. brasiliensis.

\section{REFERENCES}

1. Aristizábal BH, Clemons KV, Cock AM, Restrepo A, Stevens DA. Experimental Paracoccidioides brasiliensis infection in mice: influence of the hormonal status of the host on tissue responses. Med Mycol. 2002;40:169-78.

2. Borelli, D. Las aleurias de Paracoccidioides brasiliensis. Memorias VI Congreso Venezolano de Ciencias Médicas. 1955;4:2241-53.

3. Bustamante-Simon B, McEwen JG, Tabares AM, Arango M, Restrepo-Moreno A Characteristics of the conidia produced by the mycelial form of Paracoccidioides brasiliensis. Sabouraudia. 1985;23:407-14.

4. Calich VL, Singer-Vermes LM, Siqueira AM, Burger E. Susceptibility and resistance of inbred mice to Paracoccidioides brasiliensis. Br J Exp Pathol. 1985;66:585-94.

5. Cano LE, Arango R, Salazar ME, Brummer E, Stevens DA, Restrepo A. Killing of Paracoccidioides brasiliensis conidia by pulmonary macrophages and the effect of cytokines. J Med Vet Mycol. 1992;30:161-8.

6. Cano LE, Brummer E, Stevens DA, Restrepo A. Fate of conidia of Paracoccidioides brasiliensis after ingestion by resident macrophages or cytokine-treated macrophages. Infect Immun. 1992;60:2096-100.

7. Cano LE, González A, Lopera D, Naranjo TW, Restrepo A. Pulmonary paracoccidioidomycosis: clinical, immunological and histopathological aspects. In Lung diseases: selected state of the art reviews. Tech- Editorial. 2012. Chapter 16 p. 359-92.

8. Capilla J, Clemons KV, Stevens DA. Animal models: an important tool in mycology. Med Mycol.2007;45:657-84.

9. Caro E, Gonzalez A, Muñoz C, Urán ME, Restrepo A, Hamilton AJ, et al. Recognition of laminin by Paracoccidioides brasiliensis conidia: a possible mechanism of adherence to human type II alveolar cells. Med Mycol. 2008;46:795-804.

10. Cock AM, Cano LE, Vélez D, Aristizábal BH, Trujillo J, Restrepo A. Fibrotic sequelae in pulmonary paracoccidioidomycosis: histopathological aspects in BALB/c mice infected with viable and non-viable Paracoccidioides brasiliensis propagules. Rev Inst Med Trop Sao Paulo. 2000;42:59-66.

11. Edwards MR, Salazar ME, Samsonoff WA, Cano LE, Ostrander GA, Restrepo A. Electron microscopic study of conidia produced by the mycelium of Paracoccidioides brasiliensis. Mycopathologia. 1991;114:169-77.

12. Emmons CW, Binford CH, Utz JP. Medical mycology. $3^{\text {rd }}$ ed. Philadelphia: Lea \& Febiger; 1977.

13. Franco L, Najvar L, Gómez BL, Restrepo S, Graybill JR, Restrepo A. Experimental pulmonary fibrosis induced by Paracoccidioides brasiliensis conidia: measurement of local host responses. Am J Trop Med Hyg. 1998;58:424-30.

14. González A, Aristizábal BH, Gómez EC, Restrepo A, Cano LE. Inhibition by tumor necrosis factor-alpha-activated macrophages of the transition of Paracoccidioides brasiliensis conidia to yeast cells through a mechanism independent of nitric oxide. Am J Trop Med Hyg. 2004;71:828-30. 
15. González A, Caro E, Muñoz C, Restrepo A, Hamilton AJ, Cano LE. Paracoccidioides brasiliensis conidia recognize fibronectin and fibrinogen which subsequently participate in adherence to human type II alveolar cells: involvement of a specific adhesin. Microb Pathog. 2008;44:389-401.

16. Gonzalez A, de Gregori W, Vélez D, Restrepo A, Cano LE. Nitric oxide participation in the fungicidal mechanism of gamma interferon-activated murine macrophages against Paracoccidioides brasiliensis conidia. Infect Immun. 2000;68:2546-52.

17. González A, Gómez BL, Diez S, Hernández O, Restrepo A, Hamilton AJ, et al. Purification and partial characterization of a Paracoccidioides brasiliensis protein with capacity to bind to extracellular matrix proteins. Infect Immun. 2005;73:2486-95.

18. González A, Restrepo A, Cano LE. Role of iron in the nitric oxide-mediated fungicidal mechanism of IFN-gamma-activated murine macrophages against Paracoccidioides brasiliensis conidia. Rev Inst Med Trop Sao Paulo. 2007;49:11-6.

19. González A, Restrepo A, Cano LE. Pulmonary immune responses induced in BALB/c mice by Paracoccidioides brasiliensis conidia. Mycopathologia. 2008;165(4-5):31330 .

20. Hernández O, Almeida AJ, Tamayo D, Torres I, Garcia AM, López A, et al. The hydrolase PbHAD32 participates in the adherence of Paracoccidioides brasiliensis conidia to epithelial lung cells. Med Mycol. 2012;50:533-7.

21. Jiménez M del P, Restrepo A, Radzioch D, Cano LE, García LF. Importance of complement 3 and mannose receptors in phagocytosis of Paracoccidioides brasiliensis conidia by Nramp1 congenic macrophages lines. FEMS Immunol Med Microbiol. 2006;47:56-66

22. Lopera D, Aristizabal BH, Restrepo A, Cano LE, González A. Lysozyme plays a dual role against the dimorphic fungus Paracoccidioides brasiliensis. Rev Inst Med Trop Sao Paulo. 2008;50:169-75.

23. Lopera D, Naranjo TW, Cruz OG, Restrepo A, Cano LE, Lenzi HL. Structural and topographic dynamics of pulmonary histopathology and local cytokine profiles in Paracoccidioides brasiliensis conidia-infected mice. PLOS Negl Trop Dis. 2011;5:e1232.

24. Lopera D, Naranjo T, Hidalgo JM, de Oliveira Pascarelli BM, Patiño JH, Lenzi HL, et al. Pulmonary abnormalities in mice with paracoccidioidomycosis: a sequential study comparing high resolution computed tomography and pathologic findings. PLOS Negl Trop Dis. 2010;4:e726.

25. McEwen JG, Bedoya V, Patiño MM, Salazar ME, Restrepo A. Experimental murine paracoccidioidomycosis induced by the inhalation of conidia. J Med Vet Mycol. 1987;25:165-75.

26. McEwen JG, Restrepo BI, Salazar ME, Restrepo A. Nuclear staining of Paracoccidioides brasiliensis conidia. J Med Vet Mycol. 1987;25:343-5.
27. Mejia SP, Cano LE, Lopez JA, Hernandez O, Gonzalez A. Human neutrophils produce extracellular traps against Paracoccidioides brasiliensis. Microbiology. 2015;161(Pt 5):1008-17. doi: 10.1099/mic.0.000059.

28. Naranjo TW, Lopera DE, Diaz-Granados LR, Duque JJ, Restrepo A, Cano LE. Histopathologic and immunologic effects of the itraconazole treatment in a murine model of chronic pulmonary paracoccidioidomycosis. Microbes Infect. 2010;12(1415):1153-62.

29. Naranjo TW, Lopera DE, Diaz-Granados LR, Duque JJ, Restrepo AM, Cano LE Combined itraconazole-pentoxifylline treatment promptly reduces lung fibrosis induced by chronic pulmonary paracoccidioidomycosis in mice. Pulm Pharmacol Ther. 2011;24:81-91.

30. Negroni R. Micosis profundas. In: Las blastomicosis y coccidioidomicosis. Buenos Aires: Comisión de Investigación Científica; 1966. v. 3. (Publ. Esp. n²).

31. Neves JS, Bogliolo L. Researches on the etiologic agents of the American blastomycosis. I. Morphology and systematic of the Lutz' disease agent. Mycopathol Mycol Appl. 1951;5:133-42.

32. Pollak L. Aleuriospores of P. brasiliensis. Mycopathol Mycol Appl. 1971;45:217-9.

33. Restrepo A, Salazar ME, Cano LE, Patiño MM. A technique to collect and dislodge conidia produced by Paracoccidioides brasiliensis mycelial form. J Med Vet Mycol. 1986;24:245-8.

34. Restrepo A, Tobón AM, Cano LE. Paracoccidioidomycosis. In: Mandell, Douglas, Bennett's principles and practice of infectious diseases. $8^{\text {th }}$ ed. Philadelphia: Elsevier; 2015.

35. Restrepo BI, McEwen JG, Salazar ME, Restrepo A. Morphological development of the conidia produced by Paracoccidioides brasiliensis mycelial form. J Med Vet Mycol. 1986;24:337-9.

36. Restrepo A. A reapprasail of the microscopical appearance of the mycelial phase of Paracoccidioides brasiliensis. Sabouraudia. 1970;8:141-4.

37. Restrepo A, Moncada LH, Quintero M. Effect of hydrogen ion concentration and of temperature on the growth of P. brasiliensis in soil extracts. Sabouraudia. 1969;7:20715 .

38. Salazar ME, Restrepo A, Stevens DA. Inhibition by estrogens of conidium-to-yeast conversion in the fungus Paracoccidioides brasiliensis. Infect Immun. 1988;56:711-3.

39. Samsonoff WA, Salazar ME, McKee ML, Restrepo A, Cano LE, Edwards MR. Scanning electron microscopy of the conidia produced by the mycelial form of Paracoccidioides brasiliensis. Mycopathologia. 1991;114:9-15.

40. Tamayo D, Hernández O, Muñoz-Cadavid C, Cano LE, González A. Interaction between Paracoccidioides brasiliensis conidia and the coagulation system: involvement of fibrinogen. Mem Inst Oswaldo Cruz. 2013;108:488-93. 